Canadian University Music Review

Revue de musique des universités canadiennes

\title{
Violet Archer, Jean Coulthard, and Barbara Pentland Remembered
}

\author{
James Deaville, Claude Kenneson, William Bruneau, Elaine Keillor, Alexandra \\ Munn, Neil R. Hughes, Glenn Colton et John Beckwith
}

Volume 20, numéro 2, 2000

URI : https://id.erudit.org/iderudit/1014454ar

DOI : https://doi.org/10.7202/1014454ar

Aller au sommaire du numéro

\section{Éditeur(s)}

Canadian University Music Society / Société de musique des universités canadiennes

\section{ISSN}

0710-0353 (imprimé)

2291-2436 (numérique)

Découvrir la revue

Citer ce document

Deaville, J., Kenneson, C., Bruneau, W., Keillor, E., Munn, A., Hughes, N. R., Colton, G. \& Beckwith, J. (2000). Violet Archer, Jean Coulthard, and Barbara Pentland Remembered. Canadian University Music Review / Revue de musique des universités canadiennes, 20(2), 1-15. https://doi.org/10.7202/1014454ar
Résumé de l'article

In a bizarre coincidence, three important Canadian women composers from the same generation recently died within five weeks of each other: Barbara Pentland on 6 February 2000, Violet Archer on 22 February 2000, and Jean Coulthard on 9 March 2000. As a tribute to their lives and work, this colloquy gathers remembrances of them by friends and colleagues, ranging from brief anecdotes to extended memoirs. It is thus a collection of primary documents, which yield many new insights into the lives of our composers, ranging from personal habits to the way they taught composition.
All Rights Reserved ( C Canadian University Music Society / Société de musique des universités canadiennes, 2000
Ce document est protégé par la loi sur le droit d'auteur. L'utilisation des services d'Érudit (y compris la reproduction) est assujettie à sa politique d'utilisation que vous pouvez consulter en ligne.

https://apropos.erudit.org/fr/usagers/politique-dutilisation/ 


\section{COLLOQUYIDÉBAT: VIOLET ARCHER, JEAN COULTHARD, AND BARBARA PENTLAND REMEMBERED}

\section{EDITOR's NoTE}

\section{James Deaville}

In a bizarre coincidence, three important Canadian women composers from the same generation recently died within five weeks of each other: Barbara Pentland on 6 February 2000, Violet Archer on 22 February 2000, and Jean Coulthard on 9 March 2000. These composers were born within five years of each other (Coulthard on 10 February 1908, Pentland on 2 January 1912, and Archer on 24 April 1913), and certainly had collegial and friendly relations with each other and esteemed each other's work, even though they did not comprise a coherent school of composers. It is a striking feature of Canadian musical history that composition in the middle of the twentieth century would have such a prominent role occupied by women composers, to the extent that Archer, Coulthard, and Pentland would help shape the musical landscape of the country.

Although it has not been the practice of the Canadian University Music Review to publish reports or items about current musical life, which are better suited for publication in the Society's newsletter, the newly instituted "Colloquy" feature does allow the opportunity for us to take special note of these significant losses to Canadian music. As a tribute to these our departed mentors, colleagues, and friends, we offer here a collection of memoirs of Violet Archer, Jean Coulthard, and Barbara Pentland by individuals from their spheres of acquaintance. The result is a rich collection of the most varied remembrances about the lives of the composers, by people who worked with and studied under them. These primary documents yield many new insights into the lives of our composers, ranging from personal habits to the way they taught composition. The editor hopes that the remembrances offered here as a tribute will make these remarkable individuals come to life for us again. Unfortunately, space limitations prohibited the publication of every item submitted for inclusion, but I most sincerely thank all authors who contributed items based on their experiences with the composers.

I specially thank Glenn Colton of Lakehead University for assembling and editing the memoirs of Jean Coulthard, and Elaine Keillor of Carleton University for editing the memoir of Barbara Pentland. 


\section{VIOLET ARCHER}

\section{Claude Kenneson}

It was in Denton in 1952 that I first met Violet Archer, then composer-in-residence at North Texas State College. The following season she asked me to join my student colleagues, violinist Mary Catherine Miles and violist Carolyn Kaps, to perform her recently composed String Trio No. 1 in a recital of her chamber music works. Even after forty-seven years I remember vividly the petite dynamo of a composer coaching us vigorously on the style and spirit of her new work.

Although the paths of our lives soon diverged, we remained friends. In 1961, when I commissioned her String Trio no. 2 for the Corydon String Trio, an ensemble I had founded in Winnipeg, I thought perhaps our relationship had come full circle, but that was certainly not the case. When next I met her at a dinner party given by Zubin Mehta in Montreal, we instantly renewed our friendship. Four years later I joined her as a colleague in the theory division of the Department of Music at the University of Alberta and we had the great pleasure of a further thirty-five years as colleagues.

The Alberta years were productive for us. I continued to commission new works. The Sonata for Viola, Cello, and Piano (1976) was first played in Edmonton, then later in Toronto at the Ninth International Viola Congress by the Kenneson Trio. Capriccio for cello and piano (1981) was given its world premiere when pianist Brian Harris and I performed it at London's Wigmore Hall. My final performance as cellist of the University of Alberta String Quartet was the recording session of Violet Archer's new String Quartet no. 3 (1981), composed for the celebration of the University of Alberta's seventy-fifth anniversary.

While the exciting creation and successful performance of these new works was artistically gratifying, our friendship ran deeper than music. In retrospect, I remember best the frequent visits to her home, the twenty years of luncheons in the company of Brian Harris after her retirement from the University in 1978 , the many hundreds of random telephone calls during which we freely discussed absolutely everything about our lives-and, of course, the final call from Ottawa during which she excitedly reminded me of her recent trip to Italy and news of forthcoming performances of her music.

Violet Archer was a true friend and colleague and she will always be missed.

\section{KNOWing Violet ARCHER}

\section{William Bruneau}

I met Violet Archer briefly in the 1970s, and again in Vancouver in the 1980s. All of this changed one lovely day in February 1998. Violet agreed while visiting friends in Vancouver, and hearing performances of her work, to be interviewed. I found her at Sally Astor's place in the southern reaches of Granville Street. The house is a typical 1950s bungalow; when I arrived, the memorabilia, the sounds of tea and coffee behind double-closed doors, the smell of American cigarettes, and the no-nonsense welcome I got from Sally: all these things took one back several decades. 
Violet announced right away I mustn't pay attention to the look of the place, and even more important, not to pay attention to the look of her! It was, of course, impossible to ignore anything about Violet. She was little, and her voice (although surprisingly clear on the tape of the conversation) was always on the verge of becoming a breathy, rasping thing. At first she seemed ready to give out any minute. Two hours later, she was going strong. With Violet, appearances were deceiving. The interview could have gone on another several hours, and although I must have been thirty years younger than she, I gave out first.

I was doing research for a biography of Jean Coulthard, and asked about Violet's first acquaintance with Jean, in late 1958: "I just happened to be in the CBC in Toronto, and I met her in a large room, perhaps a studio a very long time ago. She said who she was, and I told her who I was, and that was that. So simple."

Violet knew many musicians in the Canadian West, but especially her Albertan colleagues. She was impatient about the University's slowness to adapt to change: "I wanted a very high standard in theory, and did not follow books that provided information - the run-of-the-mill harmony books-the kind used at colleges in London. Those books were so small. I immediately introduced the harmony book used at North Texas State College. And this approach attracted a fair number of students." (By this time, we were three cups of coffee in, and Violet was warming up. The raspy voice had long since gone, and she was sitting about a centimetre from the edge of the sofa.)

The Alberta "people" weren't happy at first with Violet's endless phone calls about the music curriculum, and couldn't understand where all her energy came from, but "they got used to me finally!"

I know from an earlier conversation with Tom Rolston and Isobel Moore, of the Banff Centre for the Arts, that Violet never got over her fondness for the telephone. Nearly every week night, at about seven o'clock, they came to expect an hour on the phone with Violet. She was pretty much unstoppable, always teaching and writing, and happy to work with would-be composers of every age and stage. She told me, with arm-waving, that she was

going to Ottawa, moving there. I have no less than 16 nieces and nephews ranging from age one to 53. They keep telling me, "Why can't you come and be here with us? Don't forget you're getting on, eh?"Well, I don't forget! I have a lot to do before I am finished. I have so much to do. I have so much composing yet to do.

What are you working on now?

I'm working on children's pieces.

Are they for piano?

Yes. But I've done some for violin, viola, cello, and bass, as well. And for percussion.

Have you made a systematic attempt to work your way through all the instruments?

I haven't been able to do that... yet! (typescripted interview, Violet Archer/William Bruneau, Vancouver, 12 February 1998) 
Like many a listener and enthusiast, I'll continue to enjoy Violet Archer's work, whether on the $\mathrm{CBC}$, or playing it at my own piano. But my great regret will be that I got to know Violet Archer so late.

\section{Violet ARCHER ReMEMbERED}

\section{Elaine Keillor}

While examining the sudden proliferation of music written for orchestra by Canadian composers in the 1930 s, I pondered why this happened. I posited that one main reason could have been the opportunity of more Canadians actually hearing live orchestras in the standard canon. When Archer moved to Ottawa, I was able to find out about her early orchestral experiences.

As a student at McGill University in 1930-36, Violet Archer regularly attended the Montreal (Concert) Orchestra, conducted by Douglas Clarke who became dean of the Faculty of Music in 1930. Archer told me that she initially huddled on a window sill outside to listen, but when Clarke discovered her, he formally invited her to attend rehearsals anytime. She arranged her accompanying, teaching, and studying schedule so that she could do this as well as attend concerts with scores in hand whenever possible.

Another important orchestral experience for Archer was to be a founding member of the Montreal Women's Symphony Orchestra. Its first concert conducted by Ethel Stark took place on 29 July 1940. Archer was a percussionist and indeed she had written her Capriccio for timpani and orchestra (1939) for her fellow percussionist May Fluhmann. This was actually her fourth composition involving orchestra and in 1942 Boult with the BBC Symphony performed her Britannia. The Toronto Symphony Orchestra gave the Canadian premiere under the baton of Percy Grainger in 1946.

Meanwhile, Archer had got in contact with Bartók and was commuting to New York for lessons at ten dollars each. He not only pointed out to her that to really know the symphonies of Haydn would take a lifetime of study, but that folk music was an important source for composition. She continued to perform with the Women's Symphony through 1947. Even though she began to attend Yale University that fall and was becoming thoroughly absorbed in the courses taught by Hindemith, Archer was thrilled when Stark insisted that she play in the Carnegie Hall concert. That event on 22 October 1947 was the first performance by a Canadian orchestra in New York and received excellent reviews in the press.

\section{Alexandra Munn}

I have often thought how to express my respect and friendship on this inevitable occasion and, knowing the dozens of tomes written of Violet's incredible compositional and pedagogical achievement, knew I wished to share with any, her person as a survivor.

We first met in the summer of 1962 (feels like 1862!) following our appointments, thanks to Professor Richard S. Eaton, to the then Music Division, Department of Fine Arts, University of Alberta. 
I had heard of her while a piano student of Dr. Gladys McKelvie Egbert in the early 1950s in Calgary and in 1962 was in awe of becoming a junior colleague of a living colleague-and a woman! It is difficult in the year 2000 to imagine the challenge of a young woman, Italian heritage, pianist/conductor/ composer surviving in Montreal, Quebec, and being called a WOP!

She was a fighter, determined to be permitted to express her remarkable musical gift!

I recall an Edmonton CBC radio interview hosted by Dr. Ann Burrows, OC, with Violet and myself in which she told us of writing Béla Bartók in New York City, humbly requesting lessons and enquiring his fee. She had his letter of reply with his agreeing to see her and wrote [paraphrased] "would ten dollars a lesson be agreeable?"

Our early association was personal in the sense, for example, she did not drive and often would ask me to take her shopping. On one occasion she required a small chair for the bathroom so we arrived at the Hudson Bay on Jasper Avenue and after much indecision I suggested a particular chair (the least expensive). She immediately agreed, and I bought one for my apartmentI still have it! On another occasion I asked if she wanted a warm winter coat"not really"- that resulted in her purchasing her first fur coat. Further, I remarked she was attractive and had she ever had her hair permed? "No"-another first! She subsequently made hair appointments which often were forgotten if a sudden creative rush drove her to the piano, pen, and manuscript.

She was completely unassuming, even naïve, with respect to herself and was oerwhelmed to receive accolades. Her personal life was ascetic, rather similar to the life of Manuel de Falla, and her dearest companions were her cats, particularly Jeffrey, as a recall.

Violet survived written threats from a student, requiring the presence on her property of a Commissionaire; a mugging by a teenager; a serious fall off a kitchen step stool; cancer operations; and through it all carried on her mission to compose.

Joined with that determination was her dedication in teaching young people to develop their personal creativities, and in her retirement years was even more energetic in believing in their futures by providing unflagging encouragement. A remarkable person with deep faith-a consummate musician, woman, and survivor.

\section{Neil R. Hughes}

My first memory of Violet Archer is of when I was a student at the summer music camps sponsored by the Alberta Government at Camrose Lutheran College in 1970. (The college is now Augustana University College, but the summer program continues under the name MusiCamrose.) We were playing her Three Sketches for Orchestra (BMI Canada, 1966) under conductor Marvin Rabin, and she had been invited to come from Edmonton to offer her critique of this young group-our ages ranged from about thirteen through seventeen. After she had listened to us attempt a reading, Dr. Archer was invited onstage 
by the conductor, but the steps were very steep and she declined to ascend them, stating modestly, "I have a narrow skirt." Naturally this raised a few eyebrows among us ever-so-worldly teenagers in that first heyday of the miniskirt: "What a prudish old fuddy-duddy," we thought, with the natural cruelty of youth. But immediately she raised her voice and said, "If you don't mind, I'll address you from the floor here." We were suddenly in the presence of someone who was not only very much in her milieu, but very much in charge. I shall never forget that she began by praising our efforts, which I cannot recall but which must have been very meagre indeed-this was no National Youth Orchestra, or Interlochen Arts Academy. The suggestions she made were all well within our abilities to realize, and focused deliberately on our forest of sins, rather than its innumerable trees, which proved her skills at triage in an educational setting. She talked about phrasing, dynamic contrast, and how if each player would take the responsibility to breathe in rhythm and make eye contact with the conductor on a unison attack following a rest in the second movement, everything would all come together. Later and in many interviews, she recalled her lifelong love for the symphony orchestra and how, even as a child, it was the "instrument" she really wanted to play. That day she showed a group of Alberta musical novices her mastery of her favourite instrument, and impressed upon each of us the force of the mind that occupied such a slight, almost frail body.

Five years later I found myself in her counterpoint class in the Department of Music at the University of Alberta. Here she was less at ease. Her nerves occasionally failed her in front of large groups of people when she was trying to articulate an arcane concept, and she would often disconcertingly address the wall or the chalkboard, rather than her students. Still, if one paid close attention, there was much to be learned. It is to my discredit that I was more interested at the time in playing music than in understanding or even trying to write a little of it, particularly since I was at least bright enough to grasp the close connection among all three, but laziness characterized my undergraduate years, and Dr. Archer recognized that if I had a future, it was as performer and not composer or theoretician.

During my first two years at the University of Alberta, I had the pleasure of playing in the orchestra for the premiere of her one-act opera, Sganarelle, and as was the case at Camrose, she again demonstrated her remarkable listening and assessment capabilities, helping everyone to pull a good performance together with minimal rehearsal. She had begun her adult musical life as an organist, and it is telling to me that she always seemed more adept at critiquing performance (of any music, not just her own) and assisting in rehearsals than she was at lecturing on music, at least in the classroom setting.

She attended student recitals from undergraduate through post-doctoral faithfully and without discrimination, especially (though not exclusively) when one took the trouble to invite her. Uncharitable or immature people said it was because she didn't have much of a personal life, so what else did she have to do? Nothing could have been further from the truth. Her professionalism and her sense of responsibility to all the students in the Department were both simply of an old-world order: in other words, she sincerely believed that it was 
wrong for faculty members not to attend as many student performances as time and circumstances would allow during the school year, though she would never have had the bad graces to say so to fellow faculty who were less diligent. And her appetite for music was voracious. One didn't even have to be performing a piece of new music to ensure Dr. Archer's attendance. All that was required was that one was playing music she hadn't ever heard, music she loved and hadn't heard for a long time, or music she had heard just last week but with which performance she had a few issues left unresolved in her mind. In short, Violet Archer was a symphomaniac, pure and simple. I hark back in that dreadful pun to symphony's earliest meaning, the Greek symphone, "to sound together." Of sounding together, she could not hear too much.

A final vignette. Together with the outstanding Alberta pianist Janice Waite, I performed Hindemith's Sonata for viola and piano, op. 11, no. 4, on my senior recital at the University of Alberta in March 1977. On this occasion I had been less lazy than was my custom, and acquitted myself reasonably well. Dr. Archer attended, not least because she had seen the program posted, noted that her old teacher Hindemith was on the bill, and actually went out of her way to ask me to invite her. This was unnecessary, because I knew of her connections to Hindemith and wouldn't have dreamed of not inviting her. She came backstage afterward and praised me with the words, "Hindemith himself couldn't have played it better!" Now one must remember that Dr. Archer, who was unfailingly kind to students, was occasionally given to hyperbole. And Hindemith, while a competent soloist, was never the world's greatest violist, so the compliment was not of the very highest order even though it was certainly intended as such. But what did any of that mean to a young man who was already auditioning for symphony jobs and about to graduate with his first university degree? Nothing. All that mattered was that a famous Canadian composer, a student of Hindemith, and a fixture at the University of Alberta - which I love to this dayhad given him high praise at the culmination of his four years of study, and he would never forget it. Canada has lost a great citizen, as has the world of music.

\section{JEAN COULTHARD}

\section{Claude Kenneson}

Jean Coulthard's Violin Concerto (1959) was commissioned by the Canada Council and first performed by violinist Thomas Rolston and the Vancouver Symphony Orchestra, conducted by Irwin Hoffman. Then a cellist in the VSO, I was introduced to the composer at the dress rehearsal of that fine work. I was deeply impressed then-and continued to be so over the subsequent forty years-not only by Jean Coulthard's prowess as a composer, but by her charming temperament, her sophisticated urbanity and personal charm, and her fidelity to her friends.

On 28 May 1970 the University of Alberta String Quartet, of which I was the cellist, played the world premiere at the Vancouver Art Gallery of Jean 
Coulthard's String Quartet no. 2 ("Threnody"). We performed this powerful work written for us on many occasions, but nowhere was it better received than at the 1972 Cheltenham Festival in England. That same year we joined the Purcell Quartet at the Playhouse of Vancouver's Queen Elizabeth Theatre for the premiere of Coulthard's octet, Twelve Essays on a Cantabile Theme. We later recorded both these chamber music masterpieces for the CBC International Service.

In the summer of 1971 Jean Coulthard joined us in England when pianist Brian Harris and I gave the first British performances of her Sonata for Cello and Piano (1947) at the Purbeck Festival in Dorset and later at London's Wigmore Hall. That same year she composed for me a short work for cello and piano entitled When Music Sounds... With pianist Sylvia Hunter I gave the first performance at the University of Manitoba. Ten years later, pianist Brian Harris and I performed When Music Sounds... in a 1981 Wigmore Hall recital.

It was always the greatest pleasure to be in the company of Jean Coulthard, her husband Don Adams, and their daughter Janie, but perhaps the things best remembered are the musical moments: rehearsing in her music room on Marine Drive in Vancouver, or at Alberta House in London, or at the Cheltenham Festival where we were joined by Sir Arthur Bliss and Elizabeth Maconchy, whose quartets we were also performing.

Jean Coulthard weathered the sometimes difficult years of her old age. She faced impending blindness while remaining a productive composer, continued to revel in the company of family and friends, and-always at the forefront of her chosen career-she remained ever true to herself.

\section{William Bruneau}

\section{Jean's literary acquaintances: E. M. Forster}

Jean Coulthard visited England more than a dozen times between 1928, as a student in 1928-29, and 1986, when she travelled to the south of England to revisit favourite haunts. It's hard to say if Coulthard was more Anglophile than Francophile. But certainly she loved London, and even more, she loved Hertfordshire (where her old friend and composer colleague Elizabeth Poston lived), and the coasts of Devon and Cornwall.

In the mid-1950s, she visited Cambridge with Poston by car. They travelled from Old Stevenage, where Poston lived and worked, taking "quite some time to get there; Elizabeth's ancient Austin was only just up to it."

The Postons, mother and daughter (Poston's mother was a mid-Victorian countrywoman if ever there was one, and straight out of a Hardy novel), lived in Howard's End, made famous by E. M. Forster's eponymous novel. The 1955 car trip was to see Forster in his rooms in Cambridge. Jean had met him in 1949 in Martha's Vineyard through her old Juilliard composition teacher, Bernard Wagenaar. Jean Coulthard tells the story of the outing this way (interview with William Bruneau, 6 April 1994):

Forster had been warned by letter that we were coming, and had invited us to lunch in his gorgeous rooms. I remember him shuffling across the lawn of King's 
College to meet us. But ... this was something of a shock, since there were signs everywhere warning that no man or beast should venture out on the King's Lawns.

Being a dean or whatever he was, he could walk on the grass. And since he could, we could! You know, the grass can tell if you're not the right kind of person (J. C. laughs). A beautiful lunch was brought up to his rooms, roast rabbit actually. Forster's manservant was a bit testy about our being there, two women, an unmarried Fellow, that sort of thing. Tasty lunch, though...

There's a charming strain of iconoclasm here, and a fondness for the old ways and the Old Country. No surprise that Jean Coulthard was happy to spend so many months and years on British soil.

\section{Learning composition in New York}

In October 1944, Jean Coulthard's war-time passport was endorsed to permit travel of a daughter, "baby Janey." With that document in hand, the thirty-sixyear old mother and the year-old Janey were off to New York. The objective: to study with Bernard Wagenaar, a Juilliard professor of composition recommended by Arthur Benjamin (still living in Vancouver), probably also by Barbara Pentland (living in Toronto by now), and possibly by musical acquaintances in California.

Jean was in the happy position that her maternal grandmother, and a reclusive aunt, lived on New York's Morningside Drive. The apartment was tiny, and it took a fair bit of juggling to organize the babysitting. But there were still more difficulties in this long-distance arrangement. It was, after all, far from Halifax, where her husband Don Adams was posted in the Royal Canadian Navy, and even further from her home city, Vancouver. As Jean tells it (interview with William Bruneau, 8 April 1999),

Don was by this time finishing his fourth year as a serviceman. We managed to see a fair bit of each other, but it was by no means an easy life. He'd come down in winter-time from Halifax, carrying mysterious packages wrapped in heavy brown paper. We would open them to discover fresh roasts of lamb and beef, kept near-frozen on the journey by being placed on the outside platform of the railcars on which Don rode.

New York had lots of eggs, but almost no meat. He was therefore terribly popular in Gotham.

We had hired a nurse called Ludi to help with childcare, and she enjoyed Don's visits-a natural break from her endless walks, complete with baby carriage, around the parks of uptown New York. It was now to be Don's turn to push that darned thing.

The walks were an adventure, since our building looked directly on to Harlem. But I used to walk over to Columbia University, just a few streets off, to the Library, to listen to all the String Quartets of Beethoven, the chamber works of Stravinsky, and all the rest. Over and over again, score in hand.

I worked hard with Bernard Wagenaar, but also visited Bartók for criticism lessons, and went to a concert every week, and sometimes two. New York was an education:And how we loved those lamb roasts! 


\section{England again}

It was a fact of life that at Jean's house, there would be tea. I must have consumed litres of the stuff in my five years' research on Jean Coulthard's life. Drawing on the evidence of conversations with dozens of others who visited her and husband Don Adams's various apartments and houses, tea-time was a crucial feature of daily life as early as 1950 . Where did this habit come from?

Jean's student days at the Royal College lasted just a year, 1928-29, and it would be twenty years before she returned to Happy Albion. But from 1949 until the mid-1970s, it was rare that more than three years would pass between visits to the Old Country. Jean was a happily Canadian person, but insisted on being culturally "inclusive"-long before that view of the world became acceptable, or popular. Now, her fondness for things British had behind them a century-long tradition in the families of the two Presbyterian grandfathers (in New Brunswick and in Ontario) from which she descended. The family culture was Protestant, Anglophone, and mildly imperialist.

One should put up against an equally strong fondness for all things French in the writing and making of music. Jean's mother introduced Debussy and Ravel to the Canadian west coast, and it was no accident that Jean looked up Darius Milhaud in Oakland (not just Arnold Schoenberg in Los Angeles) in her visit to California in the early 1940s. Jean thought it necessary, inevitable really, that she welcome both great streams of musical tradition.

At all events, if her reasons for spending months and years in Britain were complex, the level of her commitment was indisputably high. She tells (interview with William Bruneau, 6 April 1994) what led to her studies in 1965-66 with Gordon Jacob (Jacob's book on orchestral technique had been continuously in print since 1931) - even though her mastery of composition might suggest she need not "study with" anybody:

I applied again for a Canada Council stipend to live in London for the winter of 1965-66. I wanted to study orchestration with Gordon Jacob-to get to the bottom of it.

This produced another terrible turmoil in our family because Don, my husband, didn't want me to go. My idea was Janey would come with me, you see, to attend the Slade School of Art. Janey managed to be accepted and we had a little flat in Cornwall Mews in London.

It was dreadful. There was no heat, we were frozen half the winter and, besides, we went through all the miseries one then had to do in England.

I got hold of Elizabeth Poston, who very sweetly rang up Gordon Jacob. He took a look at my compositions, heard some tapes of my songs and other things, then turned to me and said, "I can't teach you anything. Why are you here?"

I said, "Oh, yes, you can." I had two or three scores with me and asked him to look through them.

One work we did was Endymion, which the Vancouver Symphony Orchestra played the other day. He did help me a great deal, as it turned out. I hadn't put all the woodwinds in the big climax of the piece. Not only that, I'd been too sparse in developing the outer line of the thing, and he taught 
me tricks to help bring out the melody. Of course, it changed the sound of the piece. There wasn't all that much changing, really, to do, but he loved the piece very much and said to me at the time, "I think this will be played a lot."

Which it never was, of course, in Canada.

\section{Renters}

Jean Coulthard and husband Don Adams spent several years, altogether, living in Europe, not always in the same places or at the same times. The inevitable result was a long history of people renting the Adams/Coulthard home at 2747 South West Marine Drive in Vancouver. Don's garden, carefully ordered and tended, would be handed over to a trusted gardener. And the current cleaning lady would be kept on as part of the rental.

Jean tells (interview with William Bruneau, 7 October 1999) how surprised she was in the spring of 1966 to receive a letter in London from far-away Vancouver. In it, the cleaning lady of the day (Beth) wrote in shaky handwriting to say that she just didn't know what to do. First, she discovered the renter (a nurse with a five-year old daughter) was smoking a dozen cigarillos a dayinside the house-and that the houseplants were wilting.

She had just come to do her cleaning duties at $2747 \ldots$ only to find that an allnight party had become an all-day party. Even worse, several men and women were dancing naked from the waist up. But then Beth could only see from the waste up.

Jean wrote back to counsel patience. But she also wrote several friends to arrange that they pay surprise visits for the rest of the rental period. And when Jean and Don finally moved back in, it took a week for the smell to abate.

Her final assessment: "Life is full of little surprises, but this wasn't a biggy."

\section{Glenn Colton}

I first met Jean Coulthard in 1995 to interview her as part of my doctoral research. Needless to say, it is a rare occurrence indeed that a musicologist is afforded the opportunity to meet the subject of his/her work, rarer still to find a subject who is not only a willing participant in the process, but also a warm and gracious source of encouragement and support.

Memories of that first encounter are still vivid. With a warm invitation to come in for "tea and a chat," our interview began. Fragments of the composer's creative life were everywhere to be found. The Jack Shadbolt painting that adorned her dining room served as a prominent reminder of Coulthard's long standing involvement with Canadian art and west coast artists, in particular. She was, of course, a close acquaintance of several eminent artists, including Shadbolt, Lawren Harris, Fred Varley, B. C. Binning, and Mortimer and Molly Lamb, while her husband, Donald Adams (1908-85), was an interior designer, and her daughter, Jane Adams (b. 1943), is an accomplished visual artist. The grand piano littered with manuscripts provided ample evidence of a decidedly pianistic approach to composition. She wrote extensively for the instrument (in both solo and chamber settings) and, as composer and former Coulthard pupil 
Sylvia Rickard has observed, even worked out her compositional ideas at the keyboard in her orchestral works (interview with Glenn Colton, March 1993). A quick glance out her living room window revealed a breathtaking coastal panorama, the same type of landscape that inspired so many of her compositions. Among the works in Coulthard's catalogue containing extra-musical references to the Western Canadian landscape are the Sketches from the Western Woods (1970), for solo piano; Kalamalka "Lake of Many Colours" (1973-74), for orchestra; Vancouver Lights (A Soliloquy) (1980), for soprano, baritone, SATB chorus, and orchestra; and the Ballade of the West (1983), for piano and orchestra. Even more interesting, perhaps, is the fact that the self-described dualism of Coulthard's compositional style is intrinsically linked to an internalized sense of her natural surroundings (Jean Coulthard, "Music is My Whole Life" [recorded monologue], Radio Canada International Anthology of Canadian Music, 1 [1982]):

To develop this imagery, first is the rippling, lyrical nature of sunlight glinting on the watered stone of a small brook. The other is more brooding - the depth of one's being reflected in the deep fiords of our West Coast. Many works have, of course, elements from both styles. Certain signposts do keep recurring in all my music, though I am unconscious of this at the time of writing.

After what seemed like a short time (but was actually several hours), I emerged from our interview with fascinating first hand accounts of some of the "giants" of early twentieth-century music (including Bartók and Schoenberg), useful answers to a number of analytical questions, and a richer understanding of what a uniquely special individual Jean Coulthard was.

My experience with Coulthard's solo piano music has been equally rich and rewarding. Since the early 1990s, her piano works have been the primary focus of my research and the subject of my doctoral dissertation, "The Piano Music of Jean Coulthard" (University of Victoria, 1996). As a pianist, I have had the great pleasure of giving concert performances of several of these magnificent works, including the Sonata no. 2 (1986), Image astrale (1981) and its companion piece Image terrestre (1990). I felt honoured to perform both of the latter two works in a single recital in 1995 (the first time that had been done), and have since performed Image terrestre for a CBC radio broadcast.

My research and performance activities have given me the opportunity to experience first hand many of the special qualities which make her music so memorable - the refreshingly honest expression of emotions, the ingenious formal craftsmanship, the quasi-impressionistic evocation of contrasting images and moods, the convincing integration of diverse style features and techniques into her own distinctive idiom, and her idiomatic and, at times, virtuosic approach to the piano.

Through numerous telephone conversations and correspondences in the years since our initial meeting, Jean Coulthard was a continual source of support and a true inspiration to my life as a musician. 
Jean Coulthard remained, until the very end, a warm and gracious source of encouragement to student musicians. Steven Baric, an honours music student at Lakehead University, is presently completing a critical edition of her Concerto for Piano and Orchestra (1963). Just weeks before her death, Coulthard contacted Baric by telephone to offer her personal support and thanks for undertaking the project. Countless others across Canada and around the world can do doubt recount similar stories of how this remarkable woman has touched their lives.

$$
* * *
$$

\section{Barbara Pentland}

\section{John Beckwith}

An acquantaince who emigrated to Canada in the 1960s recalls learning to play the piano at that time. From the repertoire of new music assigned by his teacherpieces by Jean Coulthard, Violet Archer, Barbara Pentland-he says he assumed that all Canadian composers were women. For several generations in fact the proportion of women among composers in Canada has often been noted as larger than the world average. The three distinguished composers named by my friend died within weeks of each other in the early months of 2000-Coulthard at 92 , Archer at 86, and Pentland at 88. Prolific producers all three, none of them could be described as feminist, and, though the topic came up regularly, none made a large issue of gender discrimination-which is not to say they never experienced it. In any listing of the most active and influential composers of their time in Canada, they would all three have to be included, and not just to fill a quota under the subheading "women composers."

This is a personal memoir by a fellow composer. Though she was the senior composer of my native province, British Columbia, during my early years, I never was closely acquainted with Jean Coulthard; but we had periodic contact-the last time, I believe, at a Queen's University conference in 1986 organized by Beverley Diamond, where Jean spoke interestingly about her long career. I met Violet Archer fairly often at professional gatherings and concerts, and recall her chirpy (sometimes strident) voice when I interviewed her for a CBC Radio program in the 1960s. Our last meeting was in Edmonton in 1997, when she invited me to tea at her little studio-home near the University of Alberta campus. Then well into her eighties and just recuperated from the nasty experience of a mugging, she talked exuberantly about a new work she had almost finished.

My professional friendship with Barbara Pentland however was longer and - more involved. In my student years in Toronto just after World War II, she was a member of the Royal Conservatory teaching staff. Preparing her Studies in Line for a piano recital, I one day knocked on her studio door and asked if I could play them for her. She was kind and encouraging. That may have been our first meeting. Around that time a fellow student, Harry Somers, performed two memorable recitals in the Conservatory Concert Hall, one devoted to his 
own piano music, and the other devoted to Barbara's. The music and his deeply committed performances were equally impressive. From 1949 I have kept the program of a summer reading session by the Conservatory Orchestra in which Victor Feldbrill, another fellow student, conducted Barbara's First Symphony; Harry Somers and I are listed as the volunteer percussionists.

Barbara by that time had departed to take up an appointment at the University of British Columbia, and I recall visiting her there around 1952 in her studio-home on the UBC campus - the standard staff housing for the period, a converted quonset hut. During the 1950 s we talked during her occasional visits to Toronto, for the 1955 annual meeting of the Canadian League of Composers, or for a League concert in 1957 when her Piano Concerto was premiered by Mario Bernardi and her former teacher, Aaron Copland, attended. Barbara was, like her colleagues Archer and Coulthard, a member of the League from its inception in 1951.

At a 1961 national conference in Toronto, Barbara's Fourth Symphony was premiered, and she and Robert Rogers performed her Klee Duets for piano four hands. She had developed a loyal following among Vancouver performers such as Rogers and later Phyllis Mailing. She was generous regarding music by colleagues (symbolic of this is her substantial support in later years of the Canadian Music Centre's Vancouver operations). When an opera of mine was broadcast by CBC Radio in 1959, she sent me a congratulatory postcard showing Picasso's Woman in Rocking Chair, a reference to the central character. In 1967 I was miffed that the organizers of a Vancouver premiere had not furnished me with a complimentary ticket, but, swallowing my pride, set out to buy one. Behind me in the box-office queue were Barbara and her husband John Huberman. When she heard of the situation, she called it an outrage and made the attendant give me my ticket.

She and John ("Hally") Huberman were a genial and hospitable pair. He was a consulting psychologist and the son of the well-known violin virtuoso Bronislaw Huberman. Hally's mother, Elza Galafrés, was still living in Vancouver in the 1960s and 1970s, a vigorous and theatrical central-European figureof the same vintage, perhaps even the same mould, as Alma Mahler Werfel.Her memoirs, Lives... Loves... Losses (Vancouver: Versatile Publishing, 1973), refer to Barbara in the later chapters.

Among Barbara's many works, I recall especially vividly the later chamber works, the Trio con alea and the Fourth and Fifth Quartets, as well as News (her commentary on the Vietnam War) and Tellus (her commentary on pollution). In her writings, there emerges a passionate voice of liberal and humanitarian feeling.

Her compositions for her own instrument, the piano, are extensive and varied. The small educational pieces are superbly calculated and often amusing and catchy as well. The larger pieces-the Suite borealis, the Fantasy, and the earlier Studies in Line, Toccata, and Rhapsody-all deserve repertoire status. Concerning the latter, composed in 1939, its subtitle "the world on the march to war again," is a clue to the recurrent rather stark marching rhythms, and a reminder of Barbara's sensitivity to her times and her surroundings. 
These days I encounter references to Barbara in biographies of various contemporaries-recently Aaron Copland and the Australian composer Peggy Glanville-Hicks, from her contacts with them during her student years in the U.S. I always wish behind such acknowledgements and tributes I could sense more awareness of her music. The Eastman-McGee study of Pentland is due to be updated. David Duke's article "Notes towards a Portrait of Barbara Pentland" (Musicworks 70, Spring 1998) may be an advance indication of further work.

The updating will have to take account of her continued outpouring of new and challenging music, declining in the 1990s only gradually with her weakening eyesight, with the sadness of Hally's death, and with the hideous onset of Alzheimer's disease. Barbara's rich creativity, her hard-working and stubborn devotion to her professional standards, and above all the legacy of her repertoire, will iemain indispensible holdings in the CanMus treasury.

\begin{abstract}
In a bizarre coincidence, three important Canadian women composers from the same generation recently died within five weeks of each other: Barbara Pentland on 6 February 2000, Violet Archer on 22 February 2000, and Jean Coulthard on 9 March 2000. As a tribute to their lives and work, this colloquy gathers remembrances of them by friends and colleagues, ranging from brief anecdotes to extended memoirs. It is thus a collection of primary documents, which yield many new insights into the lives of our composers, ranging from personal habits to the way they taught composition.
\end{abstract}

